\title{
A historical review of gravimetric observations in Norway
}

\section{Bjørn Ragnvald Pettersen}

Department of Mathematical Sciences and Technology, Norwegian University of Life Sciences, P.O. Box 5003, 1432 Ås, Norway

\author{
Correspondence to: Bjørn R. Pettersen (bjorn.pettersen@ nmbu.no)
}

Received: 26 July 2016 - Revised: 2 October 2016 - Accepted: 7 October 2016 - Published: 27 October 2016

\begin{abstract}
The first gravity determinations in Norway were made by Edward Sabine in 1823 with a pendulum instrument by Henry Kater. Seventy years later a Sterneck pendulum was acquired by the Norwegian Commission for the International Arc Measurements. It improved the precision and eventually reduced the bias of the absolute calibration from 85 to $15 \mathrm{mGal}$. The last pendulum observations in Norway were made in 1955 with an instrument from Cambridge University. At a precision of $\pm 1 \mathrm{mGal}$, the purpose was to calibrate a section of the gravity line from Rome, Italy, to Hammerfest, Norway.

Relative spring gravimeters were introduced in Norway in 1946 and were used to densify and expand the national gravity network. These data were used to produce regional geoids for Norway and adjacent ocean areas. Improved instrument precision allowed them to connect Norwegian and foreign fundamental stations as well. Extensive geophysical prospecting was made, as in other countries.

The introduction of absolute gravimeters based on free-fall methods, especially after 2004, improved the calibration by 3 orders of magnitude and immediately revealed the secular changes of the gravity field in Norway. This was later confirmed by satellite gravimetry, which provides homogeneous data sets for global and regional gravity models.

The first-ever determinations of gravity at sea were made by pendulum observations onboard the Norwegian polar vessel Fram during frozen-in conditions in the Arctic Ocean in 1893-1896. Simultaneously, an indirect method was developed at the University of Oslo for deducing gravity at sea with a hypsometer. The precision of both methods was greatly superseded by relative spring gravimeters 50 years later. They were employed extensively both at sea and on land. When GPS allowed precise positioning, relative gravimeters were mounted in airplanes to cover large areas of ocean faster than before.

Gravimetry is currently being applied to study geodynamical phenomena relevant to climate change. The viscoelastic postglacial land uplift of Fennoscandia has been detected by terrestrial gravity time series as well as by satellite gravimetry. Corrections for local effects of snow load, hydrology, and ocean loading at coastal stations have been improved. The elastic adjustment of present-day melting of glaciers at Svalbard and in mainland Norway has been detected. Gravimetry is extensively employed at offshore oil facilities to monitor the subsidence of the ocean floor during oil and gas extraction.
\end{abstract}

\section{General background}

Gravimetry (derived from Latin gravis, meaning heavy, and Greek $\mu \varepsilon \tau \rho \omega$, meaning to measure) is the empirical determination of the acceleration of gravity and its derivative, the gravity gradient. This is accomplished by observing the behavior of a test mass. Two centuries ago such observations could be made only on the surface of the Earth. Today obser- vations are collected also from ships, airplanes, and satellites. Data cover the entire planet.

The unit of the acceleration of gravity is $\mathrm{ms}^{-2}$ in the SI system. The gravity gradient has unit $\mathrm{s}^{-2}$. In geodesy and geophysics a historical remnant from the CGS system has survived, i.e., the unit $1 \mathrm{Gal}=1 \mathrm{~cm} \mathrm{~s}^{-2}$, named in honor of Galileo Galilei. In practical observations the de- 
rived quantities milligal $(\mathrm{mGal})=10^{-5} \mathrm{~ms}^{-2}$ and microgal $(\mu \mathrm{Gal})=10^{-8} \mathrm{~ms}^{-2}$ are encountered.

The gravity vector is formed by the gravitational acceleration (caused by the masses of the Earth) and centrifugal acceleration (caused by the rotation of the Earth). The gravity vector defines the local direction of the vertical. Observations from platforms in space are not affected by the rotation of the planet. External forces on the test mass (e.g., gravitation due to the Sun, Moon, and planets; tidal and loading effects; variations in the direction of the Earth axis) are small and may be corrected for by models or supplemental observations.

The test mass may be mounted on an arm balanced by a spring or by torsional forces, or it may be in free fall, or it may be a physical pendulum. The latter two involves repeated time measurements of the motions. In satellite gravimetry the entire satellite in orbit may be considered as the test mass. Orbital changes with time are analyzed to derive gravitational acceleration. Relative position changes between twin satellites and three-axis accelerometers are other approaches for dedicated gravimetric missions.

The foundation of observational gravimetry dates back to the 17th century when Galileo Galilei experimented with pendulums and the free fall of solid objects. The properties deduced formed the base for Christian Huygens' theory of the mathematical and physical pendulums. Jean Richer discovered that surface gravity changed with latitude and Isaac Newton realized that free fall was the equivalent phenomenon of planetary motion. Johan Kepler discovered empirical laws of planetary motion based on observations collected by Tycho Brahe. This led to Newton's law of gravitation in 1687. Different applications of hydrostatic equilibrium allowed Huygens and Newton to conclude that the Earth must be flattened at the poles. In the 18th century theoretical works by P. Bouguer, C. MacLaurin, and L. Euler set the foundation for A. C. Clairaut (1743) to formulate the application of gravimetry to geodetic problems.

In Norway, gravimetric observations have been collected both for scientific purposes and in support of national mapping and geophysical exploration. We primarily address the scientific perspectives in this paper but mention other applications when appropriate.

\section{The first pendulum observations in Norway in 1823}

The first technological milestone of observational gravimetry is Johann Bohnenberger's (1811) principle for a reversible pendulum. If a physical pendulum is constructed to swing around one of two rotational points such that the oscillation period is equal in both situations, it becomes unnecessary to know the location of the center of mass. Henry Kater constructed the first instrument in England in 1818. The brass physical pendulum had a test mass of $1 \mathrm{~kg}$ and an adjustable mass of $32 \mathrm{~g}$. Knife edges at either end of the $1 \mathrm{~m}$ long pendulum allowed the pendulum to be reversed. Adjustment of the small mass produced equal oscillation periods. Kater (1818) was able to obtain results in London with an uncertainty of $\pm 0.0004 \mathrm{~ms}^{-2}$ ( $\pm 40 \mathrm{mGal}$ ) (Torge, 1989). This served as a reference site and invariable pendulums were made to determine relative gravity differences between London and other locations (Kater, 1819). Expeditions were sent to remote regions of the Earth. The data collected would enter into Clairaut's theorem (1743) to estimate the flattening of the Earth.

Edward Sabine was a British naval officer and natural scientist. An expedition in the North Atlantic with The Griper allowed him to perform the first gravity observations in Norway in 1823 using invariable pendulums by Kater. The oscillation period was determined in London before and after the expedition. Sabine (1825) arrived at Hammerfest on 4 June 1823 and established a temporary observatory at Fuglenes. Small wooden sheds were covered on the outside with canvas and soil to reduce the effect of wind on the instruments. The drift of the pendulum clock was controlled astronomically by observing the Sun and stars with a Dollond transit instrument. Kater's pendulums were mounted in a separate shed $9 \mathrm{~m}$ above sea level. The oscillation periods of two pendulums were determined by 27 observation series between 9 and 22 June 1823 .

Following visits and successful observations in Greenland and Spitzbergen (now known as Svalbard), The Griper arrived at Trondheim on 8 October 1823. Sabine set up his instruments in a house located north of the city and made a temporary astronomical observatory in the garden. A room in the ground floor of the house had its floor removed to establish independent foundations for Kater's pendulum and the pendulum clock. A trigonometric determination established that the pendulum instrument was $37 \mathrm{~m}$ above mean sea level. Oscillation periods were determined by 31 observation series between 16 October and 1 November 1823.

Upon his return to England, Sabine made extensive observations at the reference site in London, e.g., to determine the effect of temperature variations. He reduced his results to local mean sea level and derived the length of a $2 \mathrm{~s}$ pendulum in Trondheim to be 39.17456 in. and in Hammerfest 39.19519 in. (Sabine, 1825). We have converted these values into gravity in SI units and listed them in Table 2 (column 2).

Sabine (1825) derived a reciprocal flattening of the Earth of 289, based on his own observations supplemented by those of Henry Kater in England and French data on the continent, a total of 25 stations between the Equator and Spitzbergen $\left(80^{\circ} \mathrm{N}\right)$. Hansteen $(1838)$ reanalyzed these data and added other stations observed by Rümker, Bessel, and the French Uranie expedition to the Southern Hemisphere. He derived a reciprocal flattening of $292 \pm 3$ (mean error), based on 33 stations with latitudes from $52^{\circ} \mathrm{S}$ to $80^{\circ} \mathrm{N}$. Contemporaneously Bessel derived $299 \pm 5$ from geodetic arc measurements. The modern value is 298.25 . 


\section{Norway's first gravity network: 1892-1903}

The first wave of international gravity observations faded out after 1830. Attempts to improve the observational precision were unsuccessful until Robert von Sterneck (1887) in Vienna miniaturized the pendulum instrument in the 1880s. His $25 \mathrm{~cm}$ pendulum was able to obtain a precision of typically $\pm 0.0002 \mathrm{~ms}^{-2}$ ( $\left.\pm 20 \mathrm{mGal}\right)$ by comparing oscillation times between sites. The best observing conditions gave $\pm 0.00005 \mathrm{~ms}^{-2}$ ( $\pm 5 \mathrm{mGal}$ ) (Torge, 1989). Sterneck provided a reference value for Vienna when delivering an instrument.

These activities were initiated as part of a multidecadal international project that began as "Mittel-Europäische Gradmessung" (Torge, 2005, 2012). Norway was among the 13 countries that joined the project in 1862 to improve the Earth ellipsoid and investigate its deviations from the real shape of the planet's equipotential surface. Other countries continued to join and the collaboration eventually developed into "Internationale Erdmessung", which in 1919 became the International Association of Geodesy (IAG), a component of the International Union of Geodesy and Geophysics (IUGG). The Norwegian contributions to the project were achieved by close collaboration between the University of Oslo and the Geographical Survey of Norway. New geodetic baselines were established in 1864 and a meridian arc from Oslo to Levanger was measured during the next several years. The orientation of the arc was determined by astronomical observations for $1868-1888$ in a dozen selected stations, which also revealed deflections of the vertical. The longitude differences between Oslo, Stockholm, and Copenhagen were determined astronomically in 1865 by telegraphic time transfer (Fearnley et al., 1890; Pettersen, 2007) and between Oslo and Bergen in 1880 (Fearnley 1884). The first tide gauges were mounted in the 1880 s to provide scale zero for a leveled height system. This refers to a potential surface in the gravity field and thus required gravity observations as well.

Physics professor O. E. Schiøtz at the University of Oslo acquired an instrument with four individual pendulums (production no. 19-22) from Sterneck in 1892 (Fig. 1), funded by the Norwegian Commission for the International Arc Measurements. Another instrument with two pendulums (production no. 33-34) was acquired for Fridtjof Nansen's Fram expedition into the Arctic Ocean. A national reference gravity station was established at the Oslo University Observatory.

When delivering the instruments, Sterneck provided observational results for the reference site in Vienna, which had a stated gravity value of $g=9.80866 \mathrm{~ms}^{-2}$. Sterneck repeatedly measured the oscillation periods of each half-second pendulum at this site, and an average value for each pendulum was provided with seven decimals. A measurement of the oscillation period $T$ at another observing site would provide a gravity value $g$ by

$\frac{g_{\text {observed }}}{g_{\text {Vienna }}}=\left(\frac{T_{\text {Vienna }}}{T_{\text {observed }}}\right)^{2}$.

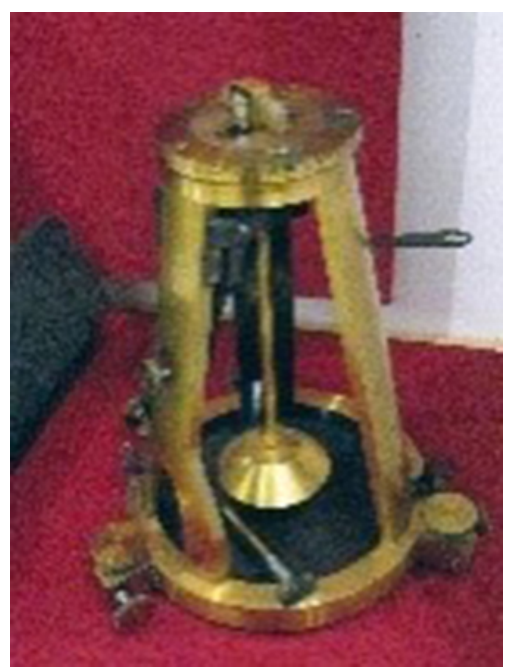

Figure 1. A Sterneck pendulum acquired in 1892, on display in the museum of the Norwegian Mapping Authority.

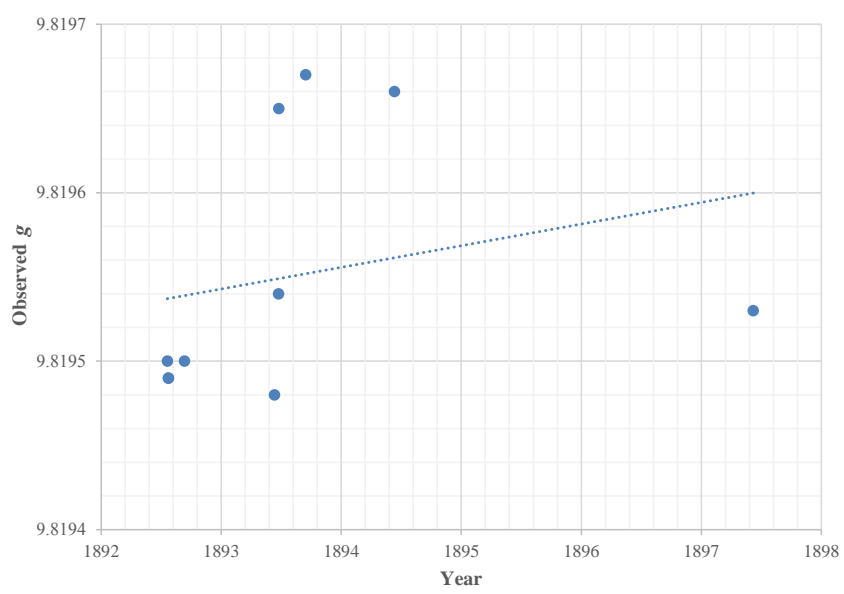

Figure 2. Repeated gravity observations at the reference site in the Oslo University Observatory.

Schiøtz $(1893,1894,1895,1901 a)$ made repeated observations at the reference site in the Oslo University Observatory with both pendulum instruments. Table 1 lists gravity values from individual observing sessions, which are plotted in Fig. 2. The average is $9.81955 \pm 0.00008 \mathrm{~ms}^{-2}$.

Between 1892 and 1903, Schiøtz (1901b, 1908) determined the acceleration of gravity at 42 sites in Norway (Fig. 3). The average value derived for the four pendulums at each site had standard deviations between \pm 0.00005 and $\pm 0.00018 \mathrm{~ms}^{-2}$.

\section{Pendulum observations in Arctic sea ice: 1893-1895}

Pendulum observations could not provide gravity values at sea because the motions of the ship affected the results. The 


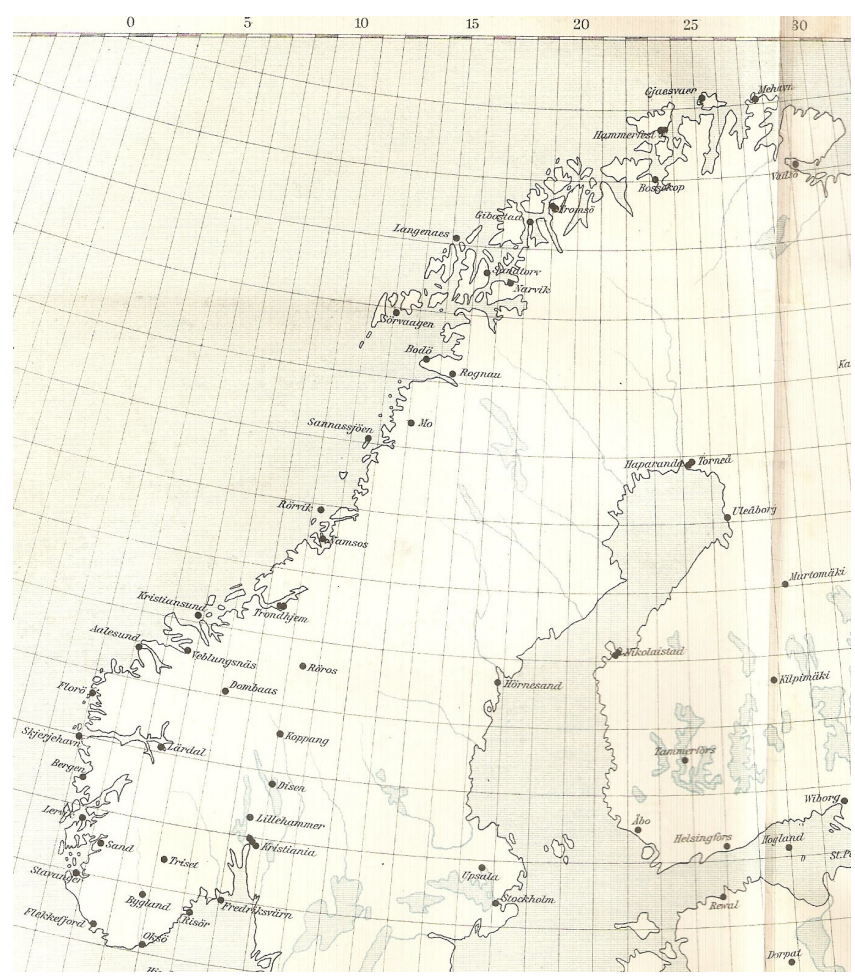

Figure 3. The first gravity network in Norway, established by pendulum observations by O. E. Schiøtz in 1892-1903. The locations around the Baltic Sea were measured by observers in other Nordic and Baltic countries.

Table 1. Gravity at the Oslo University Observatory, as observed by Sterneck pendulums 19-22 and 33-34 (labeled Fram).

\begin{tabular}{ll}
\hline Observing interval & $g\left(\mathrm{~m} \mathrm{~s}^{-2}\right)$ \\
\hline 19-21 July 1892 & $9.81950 \pm 0.00015$ \\
22-23 July 1892 & $9.81949 \pm 0.00007$ \\
21-25 July 1892 (Fram) & $9.81949 \pm 0.00013$ \\
8-15 September 1892 & $9.81950 \pm 0.00003$ \\
11 June 1893 (Fram) & $9.81948 \pm 0.00012$ \\
22-23 June 1893 & $9.81954 \pm 0.00015$ \\
23-25 June 1893 & $9.81965 \pm 0.00014$ \\
8-22 September 1893 & $9.81967 \pm 0.00016$ \\
5-17 June 1894 & $9.81966 \pm 0.00015$ \\
30 May and 13 June 1897(Fram) & $9.81953 \pm 0.00009$ \\
\hline
\end{tabular}

polar vessel Fram was constructed to withstand the forces of freezing-in with the sea ice at high latitudes. A multidisciplinary science expedition headed by professor Fridtjof Nansen was carried out in 1893-1896. Fram was taken into the ice north of Russian Siberia and remained frozen in as the currents of the Arctic Ocean transported the surface ice on a north-westerly trajectory north of Svalbard. The ship was released in 1896 and returned to Norway.

In the preface to volume II of the scientific report from the Fram expedition, Fridtjof Nansen (1901) wrote:
When I planned the expedition, I considered it not impossible that we might meet with unknown land in high latitudes; and as in such a case it would be of great importance to be able to take pendulum observations, Prof. O. E. Schiøtz kindly undertook to equip us for this purpose. [...] We met with no land in the North Polar Basin, and thus the ordinary conditions for making pendulum observations did not exist. But Scott-Hansen thought that the strong ship frozen firmly into the drifting ice, or the ice itself, might possibly afford a sufficiently solid base for the pendulum apparatus, and decided to make some observations as an experiment. Thus the first series of pendulum observations, which, to my knowledge, have ever been made over the sea, were made over the deep North Polar Basin. We had some doubt as to the value of the observations taken under such extraordinary circumstances; but thanks to Prof. Schiøtz's able elaboration and discussion of the material, it now appears that these observations afford perhaps some of the most important results of the expedition.

Sigurd Scott-Hansen made one observation in Russian Siberia in 1893 and several observations onboard Fram during the polar expedition (Schiøtz 1901a, b), between latitudes 79 and $86^{\circ} \mathrm{N}$. Three observations in June 1895 were made on the ice, outside of the vessel. It appears that some of the observations were affected by vibrational noise caused by screw ice.

\section{Pendulum results}

\subsection{Compared to an ellipsoidal Earth model}

Figure 4 compares all the observed results at the geoid ( $g$ at 53 locations reduced to sea level) with Sterneck pendulums to predicted values computed from the international gravity formula,

$\gamma=9.78049\left(1+0.0052884 \sin ^{2} \varphi\right)$,

which refers to the international ellipsoid adopted by IAG in 1924. This ellipsoid is contemporaneous with the gravity data and was derived from astrogeodetic observations in USA (Hayford, 1909). The linear fit with a regression coefficient of $R^{2}=0.991$ demonstrates that the flattening towards the pole is revealed by the data between latitude 58 and $86^{\circ} \mathrm{N}$. However, the data are not precise enough to reveal smaller-scale deviations between the gravity field and the reference ellipsoid.

This data set became the Norwegian contribution to the first realization of a global gravity system, i.e., when Borrass (1911) recomputed all gravity observations using the absolute calibration of gravity at Potsdam by Kühnen and Furtwängler (1906). 


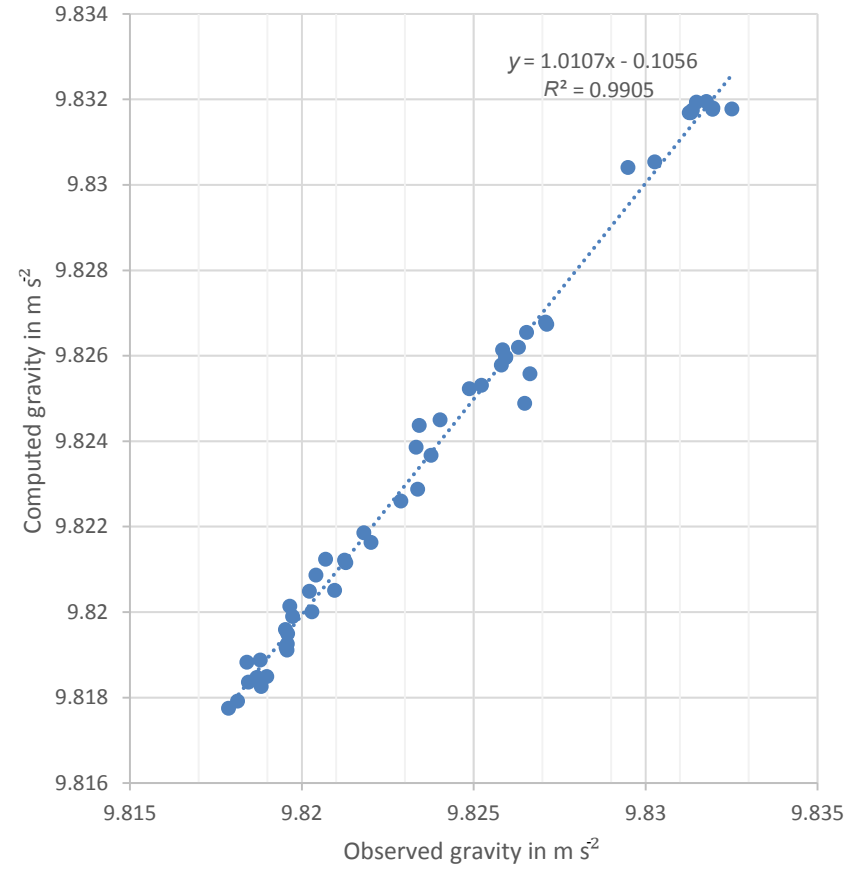

Figure 4. Computed gravity values compared to observed gravity values with Sterneck pendulums for latitudes between $58^{\circ} \mathrm{N}$ and $86^{\circ} \mathrm{N}$.

\subsection{Compared to modern absolute gravimetry}

Some of the pendulum observations in Norway were made close to sites which had recently been visited by the absolute gravimeter of the Norwegian University of Life Sciences. This allows a comparison. Observations at Bodø and Oslo were made at exactly the same locations. The other sites were at different but nearby locations. We compare results at the geoid by correcting for the orthometric height of the observing station and applying a standard Bouguer-plate approach to compensate for the gravitational effect of the masses between the geoid and the observing station. Table 2 (column 5) lists gravity values for 12 locations in Norway.

Sabine's (1825) values in Table 2 (column 2) were derived for a reference site in London. The differences from the modern values of Hammerfest and Trondheim (column 5) average to $-85 \pm 35 \mathrm{mGal}$. Schiøtz $(1901 \mathrm{~b}, 1908)$ referred his values to Vienna. The standard deviations of the gravity values in column 3 , as derived from each observation series with 4 individual pendulums, are typically $10-20 \mathrm{mGal}$. The deviations from the modern values in column 5 average to $33 \pm 18 \mathrm{mGal}$. Although measurement precision improved from Kater's pendulum to Sterneck's, the results of both Sabine and Schiøtz were significantly affected by the systematic errors of their reference values.

When the university observatory was abandoned, the Geographical Survey of Norway established a new national reference station for gravity in the basement of the Geologi- cal Museum in Oslo in 1933. Observations with the Sterneck pendulum in Potsdam and Oslo gave $g=9.81934 \mathrm{~ms}^{-2}$ (in the Potsdam system), referring to mean sea level for Oslo. In 1954 IUGG proposed a European calibration line for gravity to be established between Rome and Hammerfest. A modern pendulum apparatus from Cambridge University was used by Gunnar Jelstrup (1957) of the Geographical Survey of Norway for observations in England, Germany, Denmark, and Norway. Using a reference value from Germany (in the Potsdam system) he derived values for Oslo, Bodø, and Hammerfest. Gravity values reduced to mean sea level are listed in Table 2 (column 4). The uncertainty for each station is $\pm 0.000007 \mathrm{~ms}^{-2}( \pm 0.7 \mathrm{mGal})$, an improvement by an order of magnitude. The average deviation from the modern absolute results is $14.3 \pm 1.2 \mathrm{mGal}$ and reflects the error in the initial absolute value for Potsdam. A new observing series in Potsdam in 1968-1969 improved the accuracy by 1 order of magnitude (Schüler et al., 1971). The reference value was reduced by $13.9 \mathrm{mGal}$.

\section{Geodetic applications of new technology after World War II}

In 1946 Gunnar Nørgaard of the Danish Geodetic Institute employed two instruments of his own design to connect gravity values in Copenhagen and Oslo. He derived $g=9.819362 \mathrm{~ms}^{-2}$ (in the Potsdam system), referring to mean sea level in Oslo. The Geographical Survey of Norway acquired its own Nørgaard gravimeter in 1947. This represents the introduction of spring gravimeters to Norway. Gravity differences between Oslo and reference stations in Denmark, England, and Sweden were determined with standard deviations of $\pm 0.00001 \mathrm{~ms}^{-2}$ ( $\pm 1 \mathrm{mGal}$ ). The value derived for Oslo, referring to mean sea level, was $g=9.819378 \mathrm{~ms}^{-2}$ in the Potsdam system (Trovaag and Jelstrup, 1950). By comparing the gravity difference between Oslo and England, they concluded that the absolute gravity value for Potsdam deviated by $13 \mathrm{mGal}$. The precision and ease of operation led to spring gravimeters being the choice instrument in Norway for the second half of the 20th century.

A Worden gravimeter was acquired in 1953. It was transported on a SAS polar flight between Oslo and Anchorage, Alaska, in February 1957 (Sømod, 1957b). This was the first transfer of gravity values from the European to the Americas. Comparisons at pendulum stations in Oslo and Anchorage revealed a difference of $0.5 \mathrm{mGal}$.

During the summer of 1956 the Worden (and Nørgaard) gravimeter was employed at 101 leveling stations from Oslo at latitude $59^{\circ} 55^{\prime}$ via Bod $\varnothing$ to Hammerfest at latitude $70^{\circ} 40^{\prime}$ (Sømod, 1957a). The distance between individual stations was $20-25 \mathrm{~km}$. The purpose was to validate the gravity differences between the pendulum stations observed with the Cambridge pendulum in 1955. The Worden gravimeter was within $0.2 \mathrm{mGal}$ of the pendulum results. 
Table 2. Historical and modern gravity values referring to the geoid.

\begin{tabular}{llllll}
\hline Site & $\begin{array}{l}\text { Sabine } \\
(1825)\end{array}$ & $\begin{array}{l}\text { Schiøtz } \\
(1901 \mathrm{~b}, 1908)\end{array}$ & $\begin{array}{l}\text { Jelstrup } \\
(1957)\end{array}$ & $\begin{array}{l}\text { Absolute } g \\
\text { value (NMBU) }\end{array}$ & Latitude \\
\hline Stavanger & & 9.81869 & & 9.81843 & $58^{\circ} 58^{\prime}$ \\
Ekeberg & 9.81954 & & & $59^{\circ} 52^{\prime}$ \\
Oslo & 9.81956 & 9.81933 & 9.81918 & $59^{\circ} 55^{\prime}$ \\
Voksenåsen & & 9.81958 & & & $59^{\circ} 59^{\prime}$ \\
Bergen Obs. & 9.81958 & & & $60^{\circ} 24^{\prime}$ \\
Kolsnes & & & 9.81973 & $60^{\circ} 34^{\prime}$ \\
Ålesund & 9.82128 & & 9.82091 & $62^{\circ} 28^{\prime}$ \\
Veblungsnes & & 9.82143 & & & $62^{\circ} 33^{\prime}$ \\
Vågstranda & & & 9.82082 & $62^{\circ} 37^{\prime}$ \\
Trondheim & 9.82041 & 9.82181 & & 9.82151 & $63^{\circ} 26^{\prime}$ \\
Sandnessjøen & & 9.82376 & & 6.82344 & $66^{\circ} 01^{\prime}$ \\
Vega & & & $60^{\prime}$ \\
Bod $\varnothing$ & 9.82402 & 9.82388 & 9.82375 & $67^{\circ} 17^{\prime}$ \\
Langenes & & 9.82664 & & & $69^{\circ} 01^{\prime}$ \\
Andøya & & & 9.82616 & $69^{\circ} 18^{\prime}$ \\
Troms $\varnothing$ & 9.82593 & & 9.82560 & $69^{\circ} 40^{\prime}$ \\
Hammerfest & 9.82559 & 9.82654 & 9.82634 & 9.82619 & $70^{\circ} 40^{\prime}$ \\
Gjesvær & & 9.82709 & & & $71^{\circ} 06^{\prime}$ \\
Honningsvåg & & & 9.82663 & $70^{\circ} 59^{\prime}$ \\
\hline
\end{tabular}
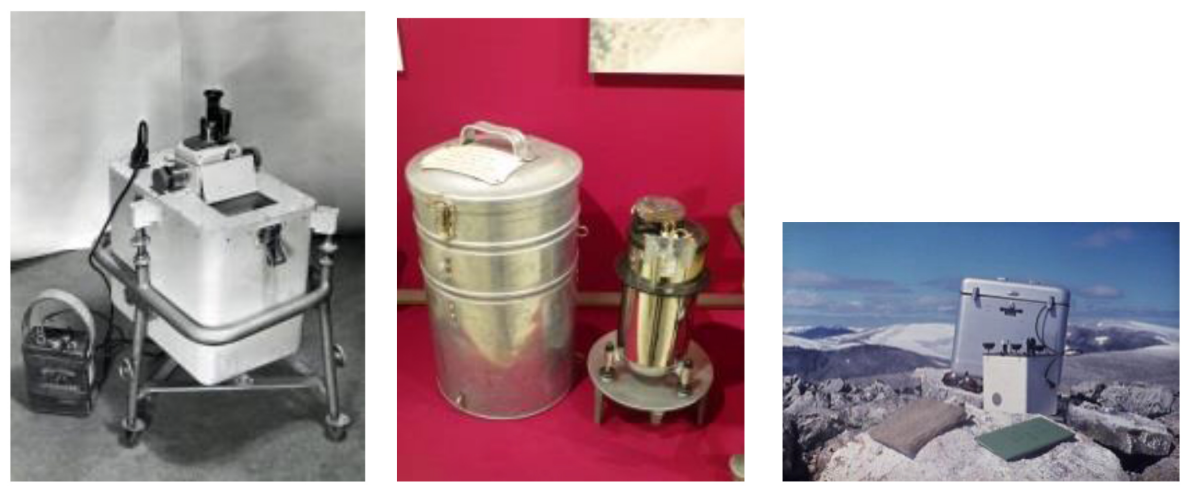

Figure 5. Relative gravimeters used in Norway: Nørgaard (left), Worden (center), and LaCoste \& Romberg (right)

Three validated control stations and the improved instrument precision now allowed for a new national gravity net to be established. Annual gravity campaigns were conducted throughout the 1950s. Between 300 and 800 stations were observed each year, mainly coinciding with leveling markers. The new network consisted of 5200 stations. In 1969 the Geographical Survey of Norway began improving and expanding this network by LaCoste \& Romberg instruments. Figure 5 shows photographs of the suite of spring gravimeters. Observations were made in closed loops to determine and correct for the daily drift of the springs. Across Norway, 36 first-order stations were established, often at airports and near highways. They served as reference stations for more than 200 second-order gravity stations, all of which were accessible by car and separated by less than $80 \mathrm{~km}$. This network was complete by 1972 (Harsson, 1973, 1978a), and selected stations became the Norwegian contribution to the new global gravity system, IGSN 71. A densification to one station per $100 \mathrm{~km}^{2}$ followed, and then further densification in selected regions. The observations continued well into the 1990s. The current database of the Norwegian Mapping Authority (institutional name change in 1986) contains 11800 stations. These data are used to generate both regional Nordic geoid models and global geoid models.

\section{Applications of terrestrial gravimetry to geophysical phenomena}

Norwegian jurisdiction in the Arctic region allowed access to islands in the high north. Following a major volcanic eruption in 1970, a gravimetric reference station was established at Jan Mayen in 1973. A network of stations southwest of the 
Beerenberg volcano was repeatedly monitored in 1976 and 1979 without detecting changes (Harsson, 1978b).

A reference station at Spitzbergen was established in 1978 and was extended to a network of gravity stations during the 1980s. In collaboration with international partners the Norwegian Mapping Authority were also engaged in the temporal variations of the gravity field and monitoring of various kinds of surface loads as measured by relative gravimeters. Long time series for the analysis of tidal effects at Spitzbergen $\left(80^{\circ} \mathrm{N}\right)$ were collected in 1969 (Melchior et al., 1970) and again in 1996, the latter with a LaCoste \& Romberg gravimeter equipped with an electronic feedback system (Bos et al., 2002).

A superconducting gravimeter has recorded the temporal changes in gravity at Ny-Ålesund, Svalbard, since 1999 (Sato el. al., 2001). Episodic calibrations have been made by absolute gravimeters. A 9-year time series reveals seasonal variability and long-term trends (Omang and Kierulf, 2011), interpreted as elastic effects from current glacier mass loss superposed on a viscoelastic response due to glacial isostatic adjustment since the last ice age.

A $80 \mathrm{~km}^{2}$ water reservoir for a hydroelectric plant in southern Norway was created by the construction of several dams in the 1980s. The accumulation of 3 billion tonnes of water created a regional load that was monitored by several geodetic and geophysical observing techniques, including gravimetry (Harsson and Bungum, 1992; Jentzsch and Koss, 1997). An elastic subsidence of $3 \mathrm{~cm}$ was recorded, with a bulge forming a few kilometers away from the lake.

Slow viscoelastic deformations due to postglacial land uplift in Fennoscandia were monitored under the auspices of the Nordic Geodetic Commission. Longitudinal arcs along the parallels at $56,61,63$ and $65^{\circ} \mathrm{N}$ have been repeatedly observed by relative gravimeters for several decades. The best coverage is at $63^{\circ} \mathrm{N}$, which has been repeated eight times since 1966 (Mäkinen et al., 2005).

Relative gravimetry on the ocean floor has been extensively employed by Statoil and collaborating partners since 1998 to monitor the vertical subsidence of offshore oil and gas production facilities in the North Sea (Eiken et al., 2008; Sasagawa et al., 2008; Zumberge et al., 2008). A recent application is to monitor the injection of $\mathrm{CO}_{2}$ into the ocean bed (Alnes et al., 2011). A unique instrument package has been developed. The relative gravimeters are routinely calibrated on land using vertical calibration lines established by an absolute gravimeter. The standard deviation of the survey observations has improved from $\pm 20 \mu \mathrm{Gal}$ in 1998 to $\pm 3 \mu \mathrm{Gal}$ at present.

The first absolute measurement of gravity in Norway was made in Hammerfest in 1976 (Cannizzo et al., 1978). A JILA instrument of the Finnish Geodetic Institute observed in Stavanger, Trysil, and Troms $\varnothing$ in 1991-1992. The improved instrument version FG5 was employed in 1993, 1995, and 1998 in a collaboration between the Norwegian Mapping Authority and institutions in Germany and USA (e.g., Klopping et

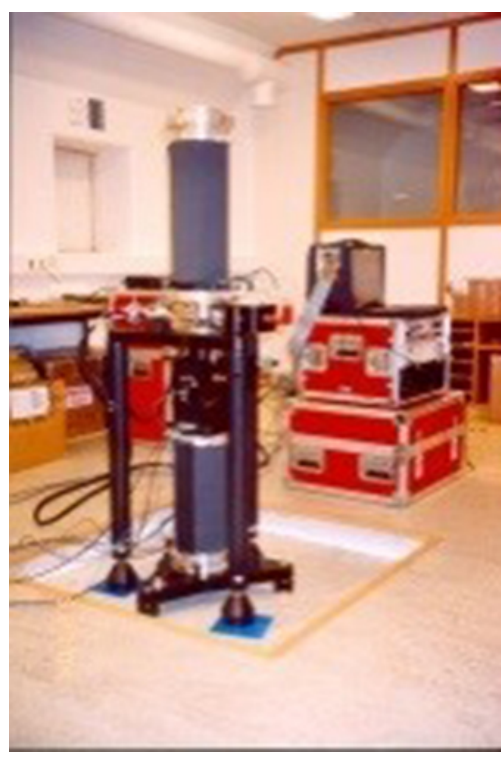

Figure 6. The free-fall absolute gravimeter FG5-226.

al., 1995). These instruments are all based on methods of free-falling test masses.

The Norwegian University of Life Sciences acquired its own FG5 instrument in 2004 (Fig. 6). It has performed annual campaigns to extend the time series and expand the network of absolute stations in Norway. A measurement precision of $\pm 2 \mu \mathrm{Gal}$ allowed testing of global ocean loading models along the Norwegian coast and to develop regional models for ocean loading corrections of gravity observations (Lysaker et al., 2008; Breili 2009a, b). A time series at an inland mountain station revealed seasonal variability in gravity due to changing precipitation, groundwater levels, and local as well as regional snow loads (Breili and Pettersen, 2009).

When corrected for short period and seasonal variability, the time series of absolute gravity values reveals secular changes specific to each observing site in Norway (Ophaug et al., 2016). Postglacial land uplift is a viscoelastic rebound from the melting of the Fennoscandian ice sheet that began about $10^{4}$ years ago. This effect is smallest along the west coast of Norway and increases towards the inner parts of the Gulf of Bothnia, the likely location of the thickest part of the ice sheet. A comparison of gravity change versus changes in geometric height provides insight into geodynamic processes of the isostatic adjustment (Pettersen, 2011).

The extensive observing program with FG5-226 has produced redundant observations for many sites. A national network of 16 stations is the most accurate reference for gravity in Norway (Breili et al., 2010).

\section{Gravity observations from moving platforms}

Gravity anomalies are essential data input for geoid determinations by Stokes' formula. An integration is required over 
the entire surface of the Earth. Thus data are required across the globe, both on land and at sea, which can be facilitated by the use of moving platforms.

\subsection{Marine gravimetry}

Pendulum observations at sea are easily corrupted by the motions of the ship. An early exception, mentioned above, was the polar vessel Fram in its frozen-in condition with the sea ice at high latitudes. To mitigate these limitations, Henrik Mohn (1899) developed an indirect method for deriving gravity with a hypsometer. At the observing station the atmospheric pressure was derived from the boiling temperature of water and was compared to the atmospheric pressure as measured simultaneously by a mercury barometer. The pressure difference was interpreted as due to the gravity difference between the observing station and a reference station (e.g., at sea level at latitude $45^{\circ}$ ). The method is sensitive to systematic errors since pressure values must be derived on the same calibrated scale. The boiling temperature must be determined with very high precision. Hecker (1903) employed this method on a cruise across the Atlantic, and later in the Indian and Pacific oceans, and the Black Sea. In total 250 observations were made. The precision was estimated to $\pm 30 \mathrm{mGal}$.

Vening-Meinesz (1929, 1941) developed a two-pendulum instrument for gravity measurements on a moving platform. Bakkelid (1959) mounted such an instrument in a submarine and measured gravity about 4 nautical miles off the coast of Norway, submerged to $30-50 \mathrm{~m}$ below the ocean surface to reduce the effects of waves. The 1957 observations from Bergen to Bodø suffered from adjustment flaws of the instrument and obtained standard deviations of $\pm 10-20 \mathrm{mGal}$. Readjustments and adding a more precise clock improved the 1958 observations from Bodø to Hammerfest to $\pm 2-4 \mathrm{mGal}$.

The University of Bergen contributed a LaCoste \& Romberg gravimeter for ocean gravimetry in 1970-1972 and 1986-1987. The surveying ship tracked the Norwegian coast and areas around Svalbard up to $81^{\circ} \mathrm{N}$.

As part of a multidisciplinary mapping of the ocean floor (http://www.mareano.no), gravimetry was included in 2008 with a ship gravimeter borrowed from USA, providing data with a standard deviation of $\pm 1 \mathrm{mGal}$. Tracks have been made in many large fiords in southern Norway and across the largest inland lake.

\subsection{Airborne gravimetry}

GPS allowed accurate positioning and made it possible to consider airplanes as vehicles for gravity observing platforms. EU funding in the 1990s opened multinational collaborations in Europe to explore and develop this method. A relative gravimeter by LaCoste \& Romberg, S-99, contributed by the University of Bergen was mounted on an inertial platform inside an airplane (Forsberg et al., 1998; Timmen et al., 2000). The observations showed a standard de- viation of about $\pm 2 \mathrm{mGal}$ (Omang et al., 2007). Tests were made in Skagerak in 1996, and extensive observing programs along the coasts of Greenland and Svalbard were made in 1998-2001 (Gidskehaug et al., 1999). Further projects covered the ocean areas between Norway, Greenland, Iceland, and Svalbard (Solheim et al., 2007). The flight plans were set up to observe new areas as well as covering areas with existing ship gravimetry. Crossover points were analyzed to merge data from ships and airplanes into one data set. One analysis focused on currents in the Fram Strait near Svalbard (Lysaker, 2009a, b).

\subsection{Satellite gravimetry}

Satellite gravimetry missions, i.e., GRACE and GOCE, have produced global data sets for derivation of the Earth's gravity field. GRACE has produced a time series revealing regional gravity change on seasonal and other timescales. Breili (2011) compared this time series with an in situ time series for Trysil obtained with an absolute gravimeter. Bentel (2013) has modeled changes of glaciers in a regional computational approach, using numerical models with radial base functions to optimize GRACE resolutions (Bentel et al., 2013).

GOCE observed the Earth's gravitational field between September 2009 and November 2013 with unprecedented spatial resolution from space. The gradiometer onboard GOCE was new technology. This required validation of the results by comparison to independent terrestrial data. Norway served as a test field (Pettersen et al., 2015; Sprlak et al., 2014). The national gravity database was recalibrated using observations with an absolute gravimeter observing simultaneously with GOCE. Algorithms and computational strategies were developed for validation of global gravity field models derived from GOCE data. National data sets of GNSS-leveling and vertical deflections were also used (Gerlach et al., 2013; Mysen, 2015; Sprlak, 2012; Sprlak et al., 2012, 2015). Improved national geoid models based on assimilated terrestrial and GOCE data allow further studies of regional sea level changes (Ophaug et al., 2015) and height system unification.

\subsection{Summary of historical driving forces}

The broad lines in this historical review reveal several driving forces and epochs for the evolution and development of observational gravimetry in Norway. The first observations by Edward Sabine in 1823 with Kater's pendulum were part of an effort to determine the flattening of the Earth by Clairaut's theorem. Locations at high latitudes were required and sites with good harbors were selected in Norway. (Sabine also observed at Spitzbergen $\left(80^{\circ} \mathrm{N}\right)$, which came under Norwegian jurisdiction a century later.) Pendulum instruments dominated gravimetry for almost 150 years and were used for both relative and absolute determinations of gravity. When 
Sterneck's miniaturized pendulum became available in the 1890 s, it was acquired to serve as part of Norway's contributions to the project Internationale Erdmessung. The scientific focus was then to determine whether deviations existed between the actual gravity field of the Earth and the mathematical model of a rotational ellipsoid. A decade of observations by O. E. Schiøtz produced the first gravity network in Norway, calibrated to a reference site in Vienna. The data set became the Norwegian contribution to the first global gravity network, referring to absolute pendulum calibrations at Potsdam in 1906. Both these calibrations suffered from systematic effects (at the 10-20 mGal level), which were revealed and corrected after World War II by improved instruments with evacuated or vacuum chambers to mitigate the effects of the air on the experiment.

When spring gravimeters were introduced in Norway immediately after World War II, it represented a paradigm shift and improved both precision and operational efficiency of relative observations. National networks were established with much higher station density than before, hinged on three reference stations with gravity values (at the $1 \mathrm{mGal}$ precision level) determined by a pendulum instrument in the mid1950s. Calibrations to absolute gravity values at the $\mu \mathrm{Gal}$ level became possible after 2004 when a free-fall gravimeter was acquired for determination of the temporal change of the gravity field across Norway.

The first-ever gravity observations at sea were made in 1894 when the Norwegian polar vessel Fram was frozen in with the sea ice in the Arctic Ocean north of Russian Siberia. Simultaneously an indirect method was developed at the University of Oslo for estimating gravity from local measurements of barometric pressure and the boiling temperature of water. It was applied for gravity determinations at several world ocean expeditions in the years before World War I. During the second half of the 20th century large ocean areas west of Norway and in the Arctic had gravity surveyed from ships and airplanes by spring gravimeters mounted on inertial platforms. The entire data set was used for improving geoid models of the Nordic region. Satellite gravimetry in the 21 st century has been validated by ground-based observations in Norway and has allowed scientific applications in geodesy, geophysics, and oceanography. Current interests also include gravimetry applied to estimating mass loss from glaciers and temporal changes on short and long timescales related to glacial isostatic processes and climate change.

\section{Data availability}

Absolute gravity data for the sites in Table 2 (column 5) are found in Breili et al. (2010), Table 3, doi:10.1080/00291951.2010.481125, and in Ophaug et al. (2016), supplemental data, doi:10.1016/j.jog.2016.09.001. The values in Table 2 (column 5) were derived by correcting for the height of the observing station above sea level.

Competing interests. The author declares no conflict of interest.

Acknowledgements. It is a pleasure to acknowledge the comments of two referees and the editor, which greatly improved the manuscript.

Edited by: K. Schlegel

Reviewed by: two anonymous referees

\section{References}

Alnes, H., Eiken, O., Nooner, S., Sasagawa, G., Stenvold, T., and Zumberge, M.: Results from Sleipner gravity monitoring, Energy Process., 4, 5504-5511, doi:10.1016/j.egypro.2011.02.536, 2011.

Bakkelid, S.: Gravity observations in a submarine along the Norwegian coast. Norges geografiske oppmåling, Geodetiske Arbeider nr. 11, 1-29, 1959.

Bentel, K.: Regional gravity modeling in spherical radial basis functions - on the role of the basis function and the combination of different observation types, Ph.D. dissertation UMB 2013:58, ISSN 1503-1667, 2013.

Bentel, K., Schmidt, M., and Gerlach, C.: Different radial basis functions and their applicability for regional gravity field representation on the sphere, Int. J. Geomathem., 4, 67-96, 2013.

Bohnenberger, J. G. F.: Astronomie, Tübingen, 778 pp., 1811.

Borrass, E.: Bericht über die Relativen Messungen der Schwerkraft mit Pendelapparaten in der Zeit von 1808 bis 1909 und über Ihre Darstellung im Potsdamer Schwerkraftsystem, Verhandlungen der sechzehnten allgemeinen Conferenz der Internationalen Erdmessung, Berlin, 1911.

Bos, M. S., Baker, T. F., Røthing, K., and Plag, H. P.: Testing ocean tide models in the Nordic Seas with tidal gravity observations, Geophys. J. Int., 150, 687-694, 2002.

Breili, K.: Ocean tide loading at elevated coastal gravity stations, Kart og Plan, 69, 151-164, 2009a.

Breili, K.: Investigations of surface loads of the Earth - geometrical deformations and gravity changes, Ph.D. dissertation UMB 2009:25, ISSN 1503-1667, 2009b.

Breili, K.: Absolutte tyngdemålinger i det 21. århundre, Kart og Plan, 71, 133-144, 2011.

Breili, K. and Pettersen, B. R.: Effects of surface snow cover on gravimetric observations, J. Geodynam., 48, 16-22, 2009.

Breili, K., Gjevestad, J. G., Lysaker, D. I., Omang, O. C. D., and Pettersen, B. R.: Absolute gravity values in Norway, Norw. J. Geogr., 64, 79-84, 2010.

Cannizzo, L., Cerutti, G., and Marson, I.: Absolute gravity measurements in Europe, Il Nuove Cimento, 1C, 39-85, 1978.

Clairaut, A. C.: Théorie de la figure de la terre, Davis Fils, Libraire, Paris, 1743.

Eiken, O., Stenvold, T., Zumberge, M., Alnes, H., and Sasagawa, G.: Gravimetric monitoring of gas production from the Troll field, Geophysics, 73, WA149-WA154, doi:10.1190/1.2978166, 2008. 
Fearnley, C. F.: General-Bericht über den Fortschritte der Arbeiten: Norwegen, in: Verhandlungen der 7ten Allgemeinen Konferenz der Europäischen Gradmessung, edited by: Hirsch, A. and Oppolzer, Th., p. 294, Georg Reimer, Berlin, 1884.

Fearnley, C. F., Schjellerup, F. C., and Lindhagen, D. G.: Längenbestimmungen zwischen den Sternwarten in Stockholm, Kopenhagen und Christiania, Kungl. Svenska VetenskapsAkademiens Handlingar, Band 24, No. 4, 52 pp., 1890.

Forsberg, R., Olesen, A. V., Timmen, L., Nesemann, M., Xu, G., Meyer, U., Boebel, T., Bastos, L., Cunha, S., Gidskehaug, A., and Hehl, K.: Geoid determination by airborne gravimetry - the AGMASCO project, second joint meeting of the International Gravity Commission and the International Geoid Commission, 7-12 September 1998, Trieste, 1998.

Gerlach, C., Sprlak, M., Bentel, K., and Pettersen, B. R.: Observation, validation, modeling - historical lines and recent results in Norwegian gravity field research, Kart og Plan, 73, 128-150, 2013.

Gidskehaug, A., Hansen, V., Solheim, D., Farelly, B., Forsberg, R., Olesen, A., Mjelde, R.: Svalbard airborne gravity project 1998, in: Proceedings EAGE 61st Conference, Helsinki, 1999.

Hansteen, C.: Capt. Sabines Pendel-Iagttagelser, Magazin for Naturvidenskaberne, 6, 309-310, 1825.

Hansteen, C.: Letter to Heinrich Christian Schumacher dated 14 April 1838, Original in Staatsbibliothek zu Berlin - Preussischer Kulturbesitz Handschriftenabteilung, 4 pp., 1835.

Harsson, B. G.: Måling av tyngdefeltet i Norge, Kart og Plan, 33, 207-212, 1973.

Harsson, B. G.: Beregning av det norske gravimeterbasisnettet, Nordisk kommisjon for geodesi, Oslo, 543-548, 1978a.

Harsson, B. G.: Gravity and Tide on Jan Mayen - preliminary report 1978, in: Proceedings of the International Workshop on Monitoring Crustal Dynamics in Earthquake Zones, edited by: Vogel, A., ISBN 978-3-528-08406-6, 1-42, 1978 b.

Harsson, B. G. and Bungum, H.: Multidisciplinary environmental monitoring of the Blåsjø reservoir area, Norway, Statens kartverk, geodetic publications 1992.

Hayford, J. F.: The figure of the earth and isostasy from measurements in the United States, US Coast and Geodetic Survey Special Publication No. 10, Washington D.C., 1909.

Hecker, O.: Bestimmung der Schwerkraft auf dem Atlantischen Ozean, sowie in Rio de Janeiro, Lissabon und Madrid, Veröff. Kgl. Preuss. Geod. Inst., Neue Folge Nr. 11, Berlin, 1903.

Helmert, F. R.: Der normale Theil der Schwerkraft im Meeresniveau, Sitz. Ber. Kgl. Preuss. Akad. der Wissenschaften zu Berlin, 328-336, 1901.

Jelstrup, G.: Observations on the gravimetric calibration base Hammerfest-Munich with the Cambridge pendulum apparatus, Norges geografiske oppmåling, Geodetiske Arbeider nr. 7, 1-70, 1957.

Jentzsch, G. and Koss, S.: Interpretation of Long-Period tilt Records at Blå Sjø, Southern Norway, with Respect to Variations in the Lake Level, Phys., Chem., Earth, 22, 25-31, 1997.

Kater, H.: An account of experiments for determining the length of the pendulum vibrating seconds in the latitude of London, Phil. Trans. Roy. Soc., London, 108, 33-102, 1818.

Kater, H.: An account of experiments for determining the variation in length of the pendulum vibrating seconds, at the principal sta- tions of the Trigonometrical Survey of Great Britain, Phil. Trans. Roy. Soc., A 109, 337-508, 1819.

Klopping, F., Mäkinen, J., Lothhammer, A., Wilmes, H., Roland, E., and Røthing, K.: Absolute gravity measurements at Nordic geodetic laboratories in Fennoscandia and Spitzbergen 19911993, J. Appl. Geophys., 34, 145-146, doi:10.1016/09269851(96)80877-9, 1995.

Kühnen, F. and Furtwängler, P.: Bestimmung der absoluten Grösse der Schwerkraft zu Potsdam mit Reversionspendeln, Veröff. Kgl. Preuss. Geod. Inst. Potsdam, Neue Folge Nr. 27, 1906.

Lysaker, D. I.: Mean dynamic topography and geostrophic surface currents in the Fram Strait derived from geodetic data, Mar. Geod., 32, 42-63, 2009a.

Lysaker, D. I.: Gravity investigations at northern high latitudes, Ph.D. dissertation, 2009b.

Lysaker, D. I., Breili, K., and Pettersen, B. R.: The gravitational effect of ocean tide loading at high latitude coastal stations in Norway, J. Geodesy, 82, 569-583, 2008.

Mäkinen, J., Engfeldt, A., Harsson, B. G., Ruotsalainen, H., Strykowski, G., Oja, T., and Wolf, D.: The Fennoscandian Land Uplift Lines 1966-2003, in: IAG Symposium No. 129, edited by: Jekeli, C., Bastos, L., and Fernandez, J., 328-332, 2005.

Melchior, P., Bonatz, M., and Blankenburgh, J.: Astro-geo project Spitzbergen, Obs. Roy. Belg. Comm. B, No. 52, Sér. Geoph., 98, 1-15, 1970.

Mohn, H.: Das Hypsometer als Luftdruckskmesser und seine Anwendung zur Bestimmung der Schwerekorrection, Skrifter, Videnskabsselskabet i Christiania, Matem. Naturvid. Klasse, No. $2,1899$.

Mysen, E.: GOCE quasigeoid performance for Norway, Int. J. Appl. Earth Obs. Geoinf., 35, 136-139, doi:10.1016/j.jag.2013.09.008, 2015.

Nansen, F.: The North Polar Expedition 1893-1896, Scientific Results Volume II, edited by: Nansen, F. and Dybwad, J., Christiania, 422 pp., 1901.

Omang, O., Solheim, D., Hunegnaw, A., Lysaker, D., Ghazavi, K., and Nahavanchi, H.: OCTAS with a focus on the importance of a high accuracy geoid, in: Gravity Field of the Earth, 13-18, General Command of Mapping, Turkey, no. 18, 2007.

Omang, O. C. D. and Kierulf, H. P.: Past and present-day ice mass variation on Svalbard revealed by superconducting gravimeter and GPS measurements, Geophys. Res. Lett., 38, L22304, doi:10.1029/2011GL049266, 2011.

Ophaug, V., Breili, K., and Gerlach, C.: A comparative assessment of coastal mean dynamic topography in Norway by geodetic and ocean approaches, J. Geophys. Res.-Ocean., 120, 7807-7826, 2015.

Ophaug, V., Breili, K., Gerlach, C., Gjevestad, J. G. O., Lysaker, D. I., Omang, O. C. D., and Pettersen, B. R.: Absolute gravity observations in Norway (1993-2014) for glacial isostatic adjustment studies: the influence of gravitational loading effects on secular gravity trends, J. Geodynam., 12 pp., doi:10.1016/j.jog.2016.09.001, 2016.

Pettersen, B. R.: Christopher Hansteens rolle i geodesiens utvikling i Norge. II, Vitenskapelige gradmålinger, Kart og Plan, 67, 38 46, 2007.

Pettersen, B. R.: The postglacial rebound signal of Fennoscandia observed by absolute gravimetry, GPS, and tide gauges, Int. J. Geophys., 3 pp., doi:10.1155/2011/957329, 2011. 
Pettersen, B. R., Sprlak, M., and Gerlach, C.: Validation of Global Gravitational Field Models in Norway. ESA-SP 728 (CD): Proceedings of 5th International GOCE User Workshop, Paris, 4 pp., 2015.

Sabine, E.: An account of experiments to determine the figure of the Earth by means of the pendulum vibrating seconds in different latitudes, Board of Longitude, 527 pp., 1825.

Sasagawa, G., Zumberge, M., and Eiken, O.: Long-term seafloor tidal gravity and pressure observations in the North Sea: Testing and validation of a theoretical tidal model, Geophysics, 73, WA143-WA148, doi:10.1190/1.2976778, 2008.

Sato, T., Asaril, K., Tamura, Y., Plag, H.-P., Digre, H., Fukuda, Y., Hinderer, J., Kaminuma, K., and Hamano, Y.: Continuous gravity observation at Ny-Alesund, Svalbard, Norway with a superconducting gravimeter CT\#039, J. Geod. Soc. Jpn., 47, 341-346, 2001.

Schiøtz, O. E.: Referat af pendelforsøg 1892, Forhandlinger i Videnskabs-selskabet i Christiania aar 1892, 27-30, 1893.

Schiøtz, O. E.: Resultate der im Sommer 1893 in dem nördlichsten Theile Norwegens ausgeführten Pendelbeobachtungen, Utgitt av den norske gradmålingskommisjon, 1-42, 1894.

Schiøtz, O. E.: Resultate der im Sommer 1894 in dem südlichsten Theile Norwegens ausgeführten Pendelbeobachtungen, Utgitt av den norske gradmålingskommisjon, 1-16, 1895.

Schiøtz, O. E.: Results of the pendulum observations, in: The North Polar Expedition 1893-1896, Scientific Results Volume II, edited by: Nansen, F. and Dybwad, J., Christiania, 1-90, 1901a.

Schiøtz, O. E.: in Verhandlungen der 13. Allgemeinen Conferenz der Internationalen Erdmessung, edited by: van de Sande Bakhuyzen, H. G., II. Teil, 223-228, 1901b.

Schiøtz, O. E.: in Verhandlungen der 15. Allgemeinen Conferenz der Internationalen Erdmessung edited by: van de Sande Bakhuyzen, H. G., II. Teil, 191-192, 1908.

Schüler, R., Harnisch, G., Fischer, H., and Frey, R.: Absolute Schweremessungen mit Reversionspendeln in Potsdam 1968-1969, Veröff. Zentralinst. für Physik der Erde Nr. 10, 1971.

Solheim, D., Omang, O. C. D., Hunegnaw, A., Drange, H., Johannessen, J., Siegismund, F., Nahavanchi, H., Ghazavi, K., Pettersen, B. R., Lysaker, D. I., Gidskehaug, A., and Plah, H.-P.: The OCTAS project, the geoid, the mean sea surface and the mean dynamic topography, in: Proceeings of the 3rd International GOCE User Workshop, Frascati, Italy, ESA SP-627, 2007.
Sprlak, M.: Validation of GOCE satellite gravity gradiometry products: Research opportunities, Kart og Plan 72, 8-19, 2012.

Sprlak, M., Gerlach, C., and Pettersen, B. R.: Validation of GOCE global gravity field models using terrestrial gravity data in Norway, J. Geod. Sci., 2, 134-143, 2012.

Sprlak, M., Pettersen, B. R., Omang, O. C. D., Lysaker, D. I., Sekowski, M., and Dykowski, P.: Comparison of GOCE global gravity field models to test fields in southern Norway, IAG Symposium No. 141: Gravity, Geoid and Height Systems, edited by: Marti, U., Springer, 59-65, doi:10.1007/978-3-319-10837-7_8, 2014.

Sprlak, M., Gerlach, C., and Pettersen, B. R.: Validation of GOCE global gravitational field models in Norway, Newton's Bulletin, 5, 13-24, 2015.

Sømod, T.: European gravimetric calibration base. Norges geografiske oppmåling, Geodetiske Arbeider nr. 9, 1-44, 1957a.

Sømod, T.: Gravimetric ties. Norges geografiske oppmåling, Geodetiske Arbeider nr. 10, 1-30, 1957b.

Timmen, L., Bastos, L., Forsberg, R., Gidskehaug, A., and Meyer, U.: Airborne gravity field surveying for oceanography, geology, and geodesy - the experience from AGMASCO, in: Geodesy beyond 2000, edited by: Schwarz, K. P., 118-123, Springer, 2000.

Torge, W.: Gravimetry, De Gruyter, Berlin, 118-123, 1989.

Torge, W.: The International Association of Geodesy 1862 to 1922: from a regional project to an international organization, J. Geodesy, 78, 558-568, 2005.

Torge, W.: 150 Years of International Cooperation in Geodesy: Precursors and the Development of Baeyer's Project to a Scientific Organization, ZfV, 137, 166-175, 2012.

Trovaag, O. and Jelstrup, G.: Gravity comparisons, published by: the Norwegian Commission for the International Arc Measurements and the Geographical Survey of Norway, Oslo, 1-53, 1950 .

Vening-Meinesz, F. A.: Theory and practice of pendulum observations at sea, Vol. I and II, Publications of the Netherlands Geodetic Commission, Delft, 1929 and 1941.

von Sterneck, R.: Der neue Pendelapparat des k. u. k. MilitärGeographischen Institutes, Mitt. d. K. K. Milit.-Geogr. Inst., VII, Wien, 7, 83-116, 1887.

Zumberge, M., Alnes, H., Eiken, O., Sasagawa, G., and Stenvold, T.: Precision of seafloor gravity and pressure measurements for reservoir monitoring, Geophysics, 73, WA133-WA141, doi:10.1190/1.2976777, 2008 . 